\title{
Design Village Tourism Package Model to Support the Application of Estate Tourism Program in East Nusa Tenggara
}

\author{
Sari Bandaso Tandilino*, Melki Kabu \\ Travel Business Study Program \\ State Polytechnic of Kupang \\ Kupang, Indonesia \\ *saribandaso@yahoo.co.id
}

\begin{abstract}
East Nusa Tenggara Province consists of hundreds of island, which are about 550 of them. However, most tourists only recognize three major islands called Flores, Sumba, and Timor, and government determines tourism development as the prime mover of the province's economy which is implemented in the development of estate tourism in seven priority destinations, namely Fatumnasi, Lamalera, Thousand Mouth, Liman Beach, Kelimutu Lake, Wolwal and Praimadita. Researcher can conclude that the main problem is the absence of making tour packages specially made by the village community in offering destination packages. This can occur due to a lack of knowledge and understanding from the village community in designing tour packages. This is very important because making an itinerary or tour package really helps the community in selling and promoting tourist destinations. The purpose of this research is to make a design model for tourism packages in the tourism estate of East Nusa Tenggara. The result is design of tour packages must be uses time distribution, the distance travelled to a destination, the total amount of costs incurred to manage the destination, and the benefits expected to obtain an alternative tour package design model in seven NTT estate tourism destinations.
\end{abstract}

Keywords-village tourism package model, East Nusa Tenggara, Estate tourism program

\section{INTRODUCTION}

UNWTO defines tourism as a human activity who undertakes and lives in a travel destination outside of their daily environment or area. Tourism has become one of the main drivers of the global economy with a very fast rate of development. The development of tourism as an industry that prioritizes services and services shows a very promising role for the economic growth of a country. This fact is probably due to the great interest of the world community who have begun to see that traveling is a necessity. The State of Indonesia has extraordinary natural wealth and a variety of different cultures and customs, scattered all over the archipelago. With this natural wealth, Indonesia can earn foreign exchange. The addition of foreign exchange in line with the creation of many jobs that provide many job opportunities. This can be seen from figure 1 the increasing number of foreign tourists visiting from 2014 to 2018 .

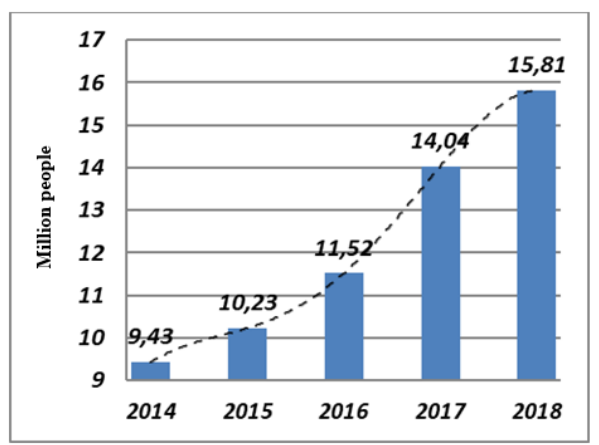

Fig. 1. Number of foreign tourists

The average growth in visits by foreign tourists (tourists) to Indonesia in the last five years (2014-2018) increased from 9.43 million people to 15.81 million people. The increasing number of tourists has made the Indonesian government continue to improve. Infrastructure development and promotion of tourist destinations are the goals of local and central governments to attract more tourists. For the State of Indonesia, tourism is a very promising sector. The government and the tourism office are trying to improve the tourism industry. So that tourism in Indonesia has its own charm, as well as has the selling power of the international economy. Of course, by improving the service, quality and quality of the Indonesian tourism sector. Indonesia has many interesting and must-visit destinations; these destinations are scattered in various provinces in Indonesia. One of them is the province of East Nusa Tenggara (NTT). NTT Province is one of the provinces in Indonesia which has many destinations and as one of the tourist destinations that have promising prospects for cultural uniqueness and natural beauty that has the potential to attract tourists, both domestic and foreign tourists. 
Indonesia consists of numerous provinces and all of them are unique. Located in the east part of the nation, East Nusa Tenggara Province has become one of the best vacation destinations especially for those who look for mesmerizing natural attractions and unique local traditions. The name of the capital is Kupang City and it even features an international airport. No wonder, the province is quite famous among foreign tourists as well. The next interesting feature of the region is the presence of famous woven fabric for tourists to buy when visiting the region. The first recognizable potential of East Nusa Tenggara Province is definitely its natural beauty. Many natural attractions are available for tourists to explore especially the beaches. That means tourists can spend beautiful holidays in those places either with friends or families. Moreover, the options are just too many so it takes much time to explore those all. Not only they can enjoy beach walking, they are able to do other fun things like snorkelling, exploration, and photography. It's seeking white sand, spectacular diving and surf, bubbling hot springs, majestic waterfalls and hidden traditional villages East Nusa Tenggara is your wonderland. Spreading west from the Wallace Line dividing Asia from Australasia, this archipelago is jungle-green in the north and tending to drier savannah in the south and east. In between are limitless surf breaks and barrels, technicolor volcanic lakes, pink-sand beaches, swaggering dragons and underwater worlds filled with colour and creatures.

The East Nusa Tenggara Provincial Government determines tourism development as the prime mover of the province's economy which is implemented in the development of estate tourism in seven priority destinations, namely Fatumnasi, Lamalera, Thousand Mouth, Liman Beach, Kelimutu Lake, Wolwal and Praimadita. The purpose of this research is to make a design model for tourism packages in the tourism estate of East Nusa Tenggara.

The development of this tourism village area includes all tourism services and accessories, namely attractions, access, accommodation, amenities, and awareness. The completeness of the 5As is the key in describing the concept of a Tourism Estate. 5A also shows the readiness of tourism destinations in meeting tourist needs. If one of them does not exist, it is said that tourism development will not succeed in boosting economic growth.

There is something unique about choosing the name tourism estate. The term Tourism Estate has never been coined by other regions or countries in formulating the concept of tourism development. This term is more widely used in small areas such as resorts or tourist areas that offer complete services such as lodging, restaurants, various tourist activities, and entertainment. All the facilities needed by tourists are there and are managed in an integrated manner in one management.

However, please note that the term estate is prone to misinterpretation. Like real estate, the concept of tourism development actually sounds like investment-based tourism development or property development. Moreover, this term is widely used by resorts that offer luxury such as Lio in El Nido in Palawan, Philippines, and the tourist area of Makaibari Tea Estate in West Bengal India, which marginalizes local farmers. However, this tourism estate defines one village as the main village and is supported by other supporting villages that are located around the village.

Based on the results of direct observations of seven destinations, questionnaires and focus group discussions that have been carried out from September 2019 to March 2020, several problems can be identified such as the number of visits to 7 destinations that increased significantly but were not followed by an increase in community income. it is unclear whether the estate tourism management institution based on community-based tourism and conceptually estate tourism as a point of centre for economic growth in the surrounding rural areas.

In the tourism awareness, people in Fatumnasi, Pramaditha, Daeama villages are still lacking, while in Wolwal and Liman it is sufficient and in Koanara and Lamalera it is high. The tourism package is only available in Koanara Village and in the other 6 villages there are no village tour packages available. And based on 6 problems, namely tourism wariness, tourism package, accommodation, accessibility, community based tourism and awareness tourism groups identified in the 7 villages, it can be concluded that only tourism packages are only available in Koanara Village while the other 6 villages are not yet available.

Yufen Dong [1] concluded that tour package planning was carried out in the form of cooperation with hotels in these destinations, Swandewi [2] concluded that the design of tour packages was carried out in coastal tourism areas, Khanan [3] concluded that the design of tour packages was based on market segmentation of visiting tourists, Syariza Abdul Rahman [4] concluded that the comparison between the uneconomic and economic itinerary, and Chung-Ling Kuo [5] concluded that there are six package tours can be planned through three traffic and transportation tools (tourist coach, railroad, and minibus) and four tourism resources (natural experiences, cultural exploration, shopping and cuisine, and event participation. Based on the conclusions of the previous researchers, it was determined that the gap in this research is on the 4Ps, namely attractions, accommodation, accessibility, amenities and awareness of tourism village communities. in receiving tourists.

\section{A. Formulation of the Problem}

How is the tour package design model in the East Nusa Tenggara Indonesia estate tourism destination?

\section{B. Research Purposes}

To compile a model for designing village tour packages in the East Nusa Tenggara Tourism Estate.

\section{Research Benefit}

NTT Province has 1,192 islands spread across 22 districts and cities and 1,114 tourist destinations are an opportunity to 
develop tourism. The vision and mission of the East Nusa Tenggara (NTT) provincial government is targeting in 2023 to have 28 estate tourism areas which currently have 7 estate tourism areas towards achieving the target of making tourism a prime mover of the economy through the achievement of NTT as a world tourism destination in 2021 .

\section{LITERATURE REVIEWS}

\section{A. Defenition of Tourism}

Tourism is an activity, service and product of the tourism industry that is able to create travel experiences for tourists [6]. Tourism as a travel activity carried out by a person or group of people by visiting certain places for the purpose of recreation, personal development, or learning the uniqueness of the tourist attraction visited in a temporary period [7]. Tourism is a variety of tourist activities and is supported by various facilities and services provided by the community, businessmen, government and local governments. Following are the types of travel [8]:

- Tour packages; a tour planned or organized by a travel agency or the risk and responsibility of which the event, place visited, accommodation, transportation, and other means have been determined by one price.

- Independent Tourism; is the opposite of a package, namely a tour that is arranged according to the wishes of tourists. This trip is not based on a time schedule, therefore this kind of tour can depart at any time you want by using any means of transportation without any ties that are arranged and carried out freely.

- Free Optimal; is a tour organized and planned by a travel agency at its own risk and responsibility. This tour is an addition to existing travel programs.

- Escorted Tour; is a tour that is planned and organized by a bureau grouped in a group led by a tour leader from the start of the trip. In this case the tour leader acts as a tour leader as well as a tour guide.

- Study tours; This term in Indonesia is known as Dharma Wisata, which is a trip undertaken by students and university students with the main objective of having a close look and studying the objects visited and the activity contains an educational element.

- Permanent Tourism; Trips that are organized with a predetermined price time are arranged by the organizing agency with many participants, the trip is carried out because the schedule is continuous.

- Social Tourism; is a trip that is planned and organized socially with the aim of giving charity and paying attention to economic and efficient factors.

\section{B. Defenition of 4 A in Tourism}

Before a destination is introduced and sold, it must first assess 4 main components, namely Attractions, Accessibility,
Amenities and Ancillary which can be explained as follows [8]:

- Attractions; At a tourist place or area, there are usually important events available at certain times. In a tour planning, attractions are very important to increase attractiveness for tourists, because it needs to be maintained so that these two things are in line, thus it is hoped that they will complement each other for the success of the tour that will be held. Thus we can avoid group members' boredom during the tour. In this case there are three factors that need to be considered, namely whether the place or area has the following requirements; There is a "something to see" factor; The existence of the "something to do" factor; There is a "something to buy" factor.

- Accessibility; Accessibility is an element that affects the cost of smoothness and convenience for a tourist who will visit attractions, such as infrastructure, roads, airports, railways, seaports. Transportation selection is also important for a tour. What type of transportation will be used, is it safe and comfortable for tourists? Safe and comfortable here, namely not jostling and huddling in the vehicle, clean and odourless transportation, suitable transportation for tourists to use. Compilers of DOT (distribution of time) in estimating road distance $(\mathrm{km})$ and travel time, need to consider the physical road conditions (damaged, smooth, jammed, or during working hours which are usually crowded with vehicles), where the bus we use must reduce speed. Often there is a delay to the destination because the tour manager does not predict the condition of the road or traffic regulations (if there are changes and are forced to turn around because the road is impassable).

- Amenities; Facilities in tourist areas are generally directed to meet various things needed by tourists during their visit. The facilities referred to here are facilities that are directly related to tourism activities, for example restaurants, accommodation, entertainment places, shopping places, and so on. Therefore, facilities in a tourist area must always be considered in terms of quality and quantity.

- Ancillary; Supporting facilities and infrastructure such as roads, telecommunications, hospitals, and so on, can be said to have no direct relationship with tourism activities. However, its existence is absolutely available in line with the development of tourism.

\section{Defenition of Tour Package}

The definition of a tour package varies widely in the literature. Tour package as a form of travel organised by tour operators, and that the tour package represents a bundle of tourism products such as accommodation, transportation and tours [9]. At least two of the products need to be marketed as one particular product to be considered a tour package. He also described the 12 interchangeable use of the term tour package 
and itinerary by tour operators. Tour package as a combination of tours, transport and accommodation, purchased in bulk by a tour operator to generate more profit and resold as part of a package [10].

A preliminary tour package design framework is proposed in picture below includes five components which are issues, stakeholders, stakeholder requirements, methodological requirements and solutions. The flow of components starts from the inner layer of the figure which is the issues, advancing from one layer to another until the final layer of the solution.

Preparation of a tour package, factors need to be considered: a. environment, especially concerning the use of tourist objects and culture / values held by the community at the tourist sites and tourists' origin ; b. target market / market for tourism products, in the sense of competitors from similar tourism products ,tourist characteristics ,tour product details ,package price eligibility; c. selection of equipment and techniques that will be used during the activity (from product preparation to post-tour products / after tourists enjoy the tour package); d. travel facilities and facilities including tourist objects ;e. quality / qualifications of the tour package manager (starting from surveys, tour planners, promotions, tour guides, etc.) ;f. laws and regulations from the local / central government as well as from the country of origin of tourists [11]. Tour package (Package tour / inclusive tour) is defined as a tour with one or more visit destinations that are compiled from certain travel facilities in a fixed travel event, and sold as a single price which concerns all components of the trip [11]. The components in a tour are transportation, accommodation, restaurants, tourist attractions and other services.

\section{RESEARCH METHOD}

The case study of this research is conducted in tourism estate East Nusa Tenggara or NTT, Indonesia. A brief introduction to tourism estate NTT is given where it justifies why the particular area is chosen for solving the tour package design issues.

The method used in this study is a qualitative descriptive method because the researcher wants to describe or describe the facts or conditions or symptoms that appear in tourist destinations so that a tour package model can be made when the research [10].

Informant Determination Techniques [10] informants must have several criteria that need to be considered, namely ; 1 . Subjects who have long and intensively merged with an activity or activity field that is the target or attention of research and this is usually characterized by the ability to provide information by rote about something being asked $; 2$. The subject is still fully engaged and active in the environment and activities that are the target or research ; 3 . The subject has sufficient time and opportunity to be asked for information ; 4 . Subjects who provide information do not tend to be processed or packaged in advance and they are relatively innocent in providing information.
Sampling Technique in this study was carried out by using purposive sampling technique, in which the selection was made deliberately based on predetermined criteria and determined based on the research objectives and criteria and informants who were appointed or selected in this study were the Head of the Provincial and District Tourism Offices, tourism awareness groups, village heads, community leaders and tourists in seven villages in East Nusa Tenggara estate tourism.

\section{A. Research Sites}

Fatumnasi Village, Uitiuh Tuan Village, Daeama Village, Praimaditha Village, Wolwal Village, Koanara Village, Uitiuh Tuan Village, and Lamalera B Village which was held from September 2019 to March 2020.

\section{B. Data Analysis Technique}

The data obtained will be analysed in a qualitative descriptive way, which consists of 3 stages [10] namely:

- Data reduction: The data obtained from the field is quite a lot, therefore it is necessary to record it carefully and in detail. As has been stated, the longer the research in the field, the more data will be, complex and complicated. For this reason, data reduction is necessary. Reducing data means summarizing, selecting the main things, focusing on the things that are important, looking for thematic patterns and removing unnecessary. Thus the data that has been reduced will provide a clearer picture, and make it easier for researchers to carry out further data collection, and search for it if needed.

- Presentation of data: After the data is reduced, the next step that the researcher must do is to display the data. Through the presentation of the data, the data is organized, a pattern of relationships is arranged, so that it will be easier to understand. The presentation of the data that has been obtained will be arranged neatly and structurally which can help researchers to draw conclusions and actions related to research.

- Verification or Conclusion: Conclusions in qualitative research may be able to answer the formulation of problems problem formulations in qualitative research are still temporary and will still develop after the research is in the field. The conclusion in qualitative research that is expected is a new finding that had never existed before. Findings can be in the form of a description or description of an object. The data that has been obtained will be concluded to answer the objectives of this study.

\section{THE RESULTS OF RESEARCH}

The results of the research are described based on the $5 \mathrm{~A}$ criterion, namely accommodation, amenities, accessibility, extraction and awareness in the East Nusa Tenggara tourism estate area. 


\section{A. Liman Beach, Semau Island}

Accommodation is available as many as 4 units (8 rooms), the amenities that are available are that PLN is stable and lives 24 hours a day without any blackouts, Telkomsel but the signal is only at certain points. Bank NTT is located in Semau District, $22 \mathrm{~km}$ from Liman beach, District Police Office in Semau District, $20 \mathrm{~km}$ from Liman beach, Accessibility from Kupang City. Attractions consist of Liman beach and Helong ethnic cultural attractions and as many as 95 tourist destinations

\section{B. Fatumnasi Village, South Central Timor, Timor Island}

Accommodation has available as many as 15 homestays and 4 cottages (8 rooms); The available amenities are the village market, Telkomsel towers, Puskesmas and BUMDES; Accessibility is the district road with heavy and light damage $(18 \mathrm{~km})$ from Soe to Kapan and the road from Kapan to Fatumnasi $10 \mathrm{~km}$ good condition and $5 \mathrm{~km}$ damaged condition, the attraction as many as 48 tourist destinations.

\section{Mulut Seribu, Rote Island}

There are 4 units ( 8 rooms) and 1 restaurant available; The available amenities are Pustu Assistant, Telkomsel, and Depot BBM; Available accessibility are state and regency roads, Wings Air serves 1 flight every day from Kupang to Rote with a travel time of about 25 minutes, wearing bells around the field as a sign of gratitude after harvest, the Thousand Mouth and as many as 80 tourist destinations

\section{Praimaditha Village , Sumba Island}

Accommodation consists of 3 cottages (6 rooms), 2 Homestay units and 1 restaurant unit; The available amenities are Telkomsel, Bank NTT, Police Station, BUMDES, Puskesmas, and clean water pipelines; The current accessibility is road access to destinations from Waingapu, which are $6 \mathrm{~km}$ of state roads, $63 \mathrm{~mm}$ of district roads, $28 \mathrm{~mm}$ of provincial roads, $2 \mathrm{~km}$ of non-status roads; Available tourist attractions are beach tourism and cultural tourism of the people of Sumba Island, as many as 351 attractions.

\section{E. Wolwal Village, Alor Island}

The accommodation available is 3 homestay units (6 rooms) and 1 cottage unit; The amenities available are clean water network, Telkomsel, Puskesmas Pembantu, Traditional Market, electricity network. Available accessibility is that Wings Air and Trans Nusa serve 1 flight every day from Kupang to Kalabahi with a travel time of about 40 minutes and PT. ASDP serves Kupang to Kalabahi shipping. Tourist attractions consist of natural tourism and cultural tourism as many as 58 tourist destinations.

\section{F. Koanara, Flores Island}

The accommodation available is 25 cottages, 4 homestays; Available accessibility is a $64 \mathrm{~km}$ long state road, Wings Air and Trans Nusa serving 1 flight per day from Kupang to Ende with a travel time of about 45 minutes and PT. ASDP serves the Kupang to Ende ferry. Tourist attractions consist of natural scenery; Kelimutu Lake, and as many as 68 tourist destinations; Amenitas are available, namely 8 units of restaurants, ATMs, markets, health centres, Telkomsel, Bumdes and fuel depots.

\section{G. Lamalera, Lembata Island}

Currently available accommodation is 20 homestay units; The available amenities include a weak Telkomsel signal, Bumdes, electricity only at night, barter market, Banks; The available accessibility is air transportation from Kupang to Lewoleba for 45 minutes using the Trans Nusa plane, sea transportation, there are many options such as Ferry and Pelni boats, from lewoleba to Lamalera B village taken for 4 hours with road access about $50 \mathrm{~km}$ heavily damaged. The tourist attractions available are whale hunting.

\section{DISCUSSION}

Based on the results of a study on 7 estate tourism areas in East Nusa Tenggara, the preparation of tour packages can be carried out as a system that is interrelated with the following arrangement:

\section{A. Tour Packages as a Tourist Subsystem}

Tour package products are structured as a product that is oriented towards consumers (tourists) because it is a very dominant factor affecting the products being sold. Knowledge of tourist profiles or behaviour is very helpful in finding the tourism products that they will choose. Broadly speaking, tourist profiles consist of physical profiles (name, place of birth, age, gender, religion, occupation, nationality) and nonphysical profiles (psychological behaviour, consistency and complexity, psychography, opinions, tourist typology, groups and individuals. motivation, emotions)

\section{B. Tour Packages as a Tourist Attraction Subsystem}

Tourist attractions as an intangible service can attract a person so that they travel to achieve it and can give satisfaction to that person for the activities carried out at the tourist attraction site. Some points that need to be considered in placing tourist attractions on a tour package are stop points (as main attractions, additional attractions), facilities, services and conditions of tourist attractions at the location (topography or contour, geographic location, relations with other attractions), distance (from the point at the beginning, with other attractions, with hotels, terminals, other cities and with tourist facilities) exploration costs of tourist attractions, accessibility to reach tourist attractions (distance, time, cost) types of natural tourist attractions (natural beauty, climate / weather, water attractions , flora and fauna) type of cultural tourism attraction (exotic culture, tradition or habit, ethnicity, modern culture, historical attractions 


\section{Tour Packages as a Facility Subsystem}

For destination facilities, several things that are included in the preparation of the tour package are accommodation facilities (form of accommodation, room capacity, price, location of accommodation, ease of reaching accommodation, sanitation and hygiene. Uniqueness) restaurant facilities (form of restaurant, visitor capacity, menu price, facilities and services). services, location, accessibility, operating hours) transportation facilities (mode of transportation, mode conditions, prices, travel and travel schedules, location) performance facilities (facilities and services, performance forms, prices, locations) and tourist shopping places (products offered, packing system, route in the direction of destination, price).

\section{Tour Packages as a Time Subsystem}

Time in the preparation of tour packages can be in the form of internal and external considerations relating to facilities, costs, and places as well as factors of boredom and fatigue for tourists. The available time is determined by the tour organizer used for tour activities, on board activities and the remaining time that is still available. The use of time for the tour must be the longest because of the tour and it takes the presence of a guide. The use of the remaining time (rest) is used for other activities outside the tour, for example for taking pictures, gathering tour participants, taking breaks by following the tour operator stages as a tour planner, filling out the time distribution according to the needs in the old form and the trip schedule is carried out. After adjusting to the time constraint, the time distribution will be adjusted according to the time allocation. The time distribution obtained from the time adjustment from a product point of view is called time distribution planning.

Based on the results of his research and discussion above, a tour package planning model and quotation tour package can be described in 7 tourism estates in East Nusa Tenggara as follows:

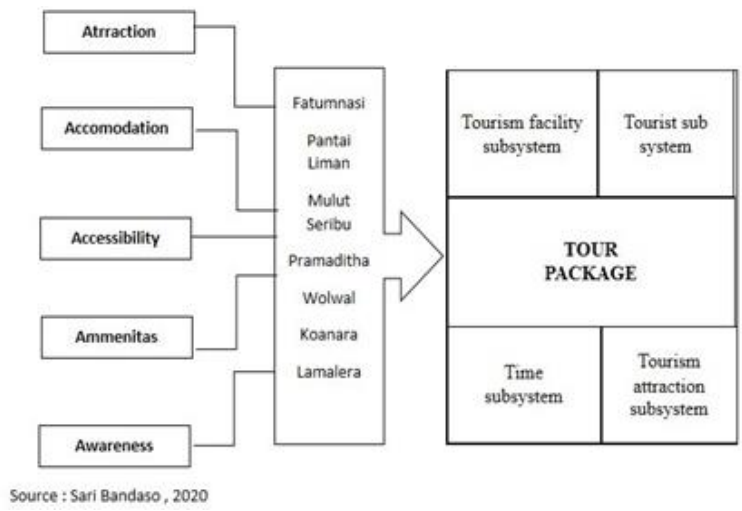

Fig. 2. Tour package planning model.

Based on the above model, it can be explained that the factors of tourist attractions, accommodation that have been prepared, access to transportation to destination locations, and supporting facilities such as health facilities, telecommunications, and the level of public awareness of accepting tourists are determining factors in making tour packages in 7 tourism destinations in East Nusa Tenggara and as one of the results of this study, the itinerary of the Konara Tourism Village, Ende District, can be explained in the following

Based on the results of the calculation of fixed costs consisting of vehicle rental, guide services, while variable costs consisting of rental fees for entry to destination locations, food and drinking costs and other costs are obtained as much as IDR $2,725,000$. After that, add a profit cost of $15 \%$ or IDR 492,750 . Then add another tax of $1 \%$ or IDR 37,777 so that the cost of selling Koanara Village tour packages for 1 tourist is IDR $3,815,527$ or USD 263.14 .

\section{CONCLUSION}

- Factors of tourist attractions, accommodation that have been prepared, access to transportation to destination locations, and supporting facilities, and the level of public awareness of accepting tourists are determining factors in making tour packages in 7 tourism destinations in East Nusa Tenggara.

- Of the 7 tourism estate locations, only in Koanara Village, Ende District, where the level of community involvement is high in making tour packages, while the other 6 villages still need practical training.

\section{REFERENCES}

[1] Y. Dong, L. Ling and X. Guo, "Travel package modeling: optimal bidding strategy of tour operator to cooperative hotels," Asia pacific journal of tourism research, vol. 19, no. 12, pp. 1417-1440, 2014

[2] J. Susanti and I.G. Karma, "Developing tour package price system in travel bureau companies," International Journal of Applied Sciences in Tourism and Events, vol. 3, no. 1, pp. 1-11, 2019.

[3] M.F.B. Abdul Khanan, Development of tour packages through spatiotemporal modelling of tourist movements (Doctoral dissertation, Curtin University), 2014.

[4] S.A. Rahman, A.M. Benjamin and E.M.N.E.A. Bakar, "Economic tour package model using heuristic," In AIP Conference Proceedings, vol. 1605, no. 1, pp. 1160-1165, 2014.

[5] C.L. Lin and C.L. Kuo, "A service position model of package tour services based on the hybrid MCDM approach," Current issues in tourism, vol. 22, no. 20, pp. 2478-2510, 2019.

[6] O.A. Yoeti, Tours and Travel Marketing. Jakarta, PT. Pradnya Paramita, 2008.

[7] J. Jafari, Encyclopedia of tourism. London: Routledge, 2000.

[8] G. Syratt and J. Archer, Manual of travel agency practice. Oxford, 2003.

[9] N. Nuriata, Paket Wisata Penyusunan Produk dan Penghitungan Harga. Bandung: Alfabeta, 2014

[10] S. Sugiyono, Metode Penelitian Bisnis. Bandung: Alfabeta, 2013

[11] H. Askari, "Demand for package tours," Journal of Transport Economics and Policy, pp. 40-51, 1971. 